\title{
Survei Intervensi Ibu Hamil Kurang Energi Kronik (KEK) di Kecamatan Jatinangor Tahun 2015
}

\author{
Arsy Prawita ${ }^{1}$, Ari Indra Susanti ${ }^{2}$, Puspa Sari ${ }^{2}$ \\ ${ }^{1}$ Program Diploma Kebidanan, Fakultas Kedokteran Universitas Padjadjaran \\ ${ }^{2}$ Departemen Ilmu Kesehatan Masyarakat, Fakultas Kedokteran Universitas Padjadjaran
}

\begin{abstract}
Abstrak
Kurang Energi Kronik (KEK) adalah kurangnya asupan energi berlangsung lama. Pada ibu hamil KEK merupakan keadaan ibu hamil menderita kekurangan energi yang berlangsung menahun sehingga menimbulkan gangguan kesehatan. Untuk mencegah gangguan kesehatan, faktor risiko serta komplikasi, maka dilakukan intervensi. Tujuan penelitian ini adalah melakukan survei intervensi pada ibu hamil KEK di Kecamatan Jatinangor tahun 2015. Metode penelitian menggunakan metode deskriptif dengan pendekatan cross-sectional. Diambil dari data sekunder kohort, penapisan gizi, dan buku KIA pada tahun 2015 di Kecamatan Jatinangor. Sampel yang digunakan, $112 \mathrm{ibu}$ hamil KEK. Setelah diberikan kriteria inklusi dan eksklusi, sampel jumlah ibu hamil KEK menjadi 33 orang. Analisis data menggunakan univariat, dilakukan dengan perhitungan statistik kemudian ditampilkan dalam tabel distribusi frekuensi. Hasil penelitian didapatkan ibu hamil KEK yang mendapatkan intervensi sebanyak 29.5\%. Sedangkan intervensi berdasarkan penambahan berat badan (BB) dan penambahan lingkar lengan atas (LiLA) yaitu 100\%, intervensi berdasarkan konseling kesadaran gizi (kadarzi) yaitu 100\% dan intervensi berdasarkan pemberian makanan tambahan (PMT) yaitu 36,3\%. Kesimpulan penelitian ini adalah seluruh ibu hamil KEK diberikan intervensi penambahan BB, LiLA, dan konseling Kadarzi, dan hanya sebagian ibu hamil KEK mendapatkan PMT di Kecamatan Jatinangor Tahun 2015.
\end{abstract}

Kata Kunci : Ibu Hamil dengan KEK, Intervensi, Survei

\section{Intervention Survey of Pregnant Women Less Energy Chronic (KEK) in District Jatinangor 2015}

\begin{abstract}
The chronic energy deficiency (CED) is the lack of energy intake in a long period of time. The condition of pregnant women with CED are the condition where they suffer from the lack of energy which lasts for years, so that it causes health problems in them. To prevent the health problems, risk factors, as well as the complication, interventions was done to solve them. The objective of this research was to do a interventions survey on pregnant women with CED in Jatinangor Work Region in 2015. The research method used was descriptive with crosssectional approach. It was taken secondary data from cohort, nutritional screening, and pregnancy book in 2015 in Jatinangor. The samples employed were 112 pregnant women with CED. After being given the inclusion and exclusion criteria, number of pregnant women with CED become 33 people. The data analysis used was univariate, done with statistical measurement, then it was shown in frequency distribution table. The research result obtained that pregnant women with CED given intervention was 29,5\%. Meanwhile, intervention given based on increase weight $(W)$ and mid upper arm circumference (MUAC) was 100\%, intervention given based on nutritional awareness counseling (Kadarzi) was $100 \%$, and intervention based on supplementary feeding (PMT) was 36,3\%. The conclusion of this research was that all pregnant women with CED were given additional intervention weight, MUAC, and Kadarzi counseling, and that only some of them got PMT in Jatinangor Work Region.
\end{abstract}

Keywords : Intervention, Pregnant Women with CED, Survey

\author{
Korespondensi: \\ Arsy Prawita \\ Program Studi Diploma Kebidanan, Fakultas Kedokteran Universitas Padjadjaran \\ Jl. Bandung - Sumedang KM. 21 Jatinangor \\ Mobile : 085603113989 \\ Email : prawita.arsy@gmail.com
}




\section{Pendahuluan}

Sustainable Development Goals (SDG's) merupakan cara baru untuk menanggulangi masalah kesehatan. SDG's ini memiliki 17 tujuan, salah satunya adalah poin ke-2 tentang menanggulangi kelaparan yang berkaitan dengan kekurangan gizi. ${ }^{1}$ Sebagai masalah kesehatan masyarakat, gizi yang optimal sangat penting untuk kesehatan reproduksi yang normal. Setiap kali kebutuhan energi tidak terpenuhi dalam jangka panjang, maka menghasilkan energi yang sedikit, menyebabkan kekurangan energi kronis. Pada wanita hamil dan wanita menyusui, kekurangan energi kronis memiliki dampak terburuk. $^{2}$

Kekurangan gizi pada ibu dan bayi telah menyumbang setidaknya 3,5 juta kematian setiap tahunnya dan menyumbang $11 \%$ dari penyakit global di dunia. Menurut survei dari Ethiopian Demographic and Health Survey (EDHS) di negara berkembang tahun 2014 untuk masalah kekurangan gizi di Kerala (India) berkisar 19\%, Bangladesh (Asia) sekitar 34\%, dan di daerah kumuh Dhaka sekitar 34\%. Penelitian EHDS selanjutnya juga mengungkap perempuan yang menikah kurang dari 18 tahun lebih memungkinkan untuk kekurangan gizi dibandingkan dengan lebih dari 18 tahun. Hal ini disebabkan, pernikahan di usia dini sering kehilangan anak, tidak mempunyai rencana menjadi ibu, dan sering aborsi. ${ }^{3}$

Survei Kesehatan Keluarga di India juga menunjukan bahwa perempuan dengan usia subur lebih sering atau paling rentan terhadap kekurangan gizi. ${ }^{2}$ Dampak kekurangan gizi pada ibu hamil juga dapat menyebabkan risiko komplikasi antara lain, anemia, perdarahan, BB ibu tidak bertambah secara normal dan penyakit infeksi. ${ }^{4,5}$

Kekurangan energi kronis adalah manifestasi penting dari kekurangan gizi buruk dan juga kedua masalah utama di negara berkembang. Berdasarkan hasil Riset Kesehatan Dasar (Riskesdas) di Indonesia tahun 2013, Kurang Energi Kronik (KEK) menjadi masalah yang kedua. Hal ini disebabkan karena angka KEK mengalami peningkatan dari tahun 2010 yaitu $31,3 \%$ menjadi $38,5 \%$ di tahun $2013 .{ }^{6}$ Menurut Badan Puslitbang Gizi dan Makanan Depkes RI di Jawa Barat pada tahun 2005, angka kejadian KEK 30,6 \% dengan yang paling rendah di Kota Cimahi sekitar $19,5 \%$ dan yang tertinggi di daerah Kabupaten Purwakarta sekitar 50,7\%. Untuk daerah Kabupaten Sumedang sendiri mencapai $29,7 \% .^{7}$ Data di atas menunjukan, angka tersebut cukup tinggi mengingat cakupan target pemeriksaan ANC menurut Rencana
Strategis Kementrian Kesehatan (Renstra 2013) yang meliputi pemeriksaan Lingkar Lengan Atas (LILA) untuk K1 dan K4 adalah 93\%. ${ }^{8}$ Gambaran di atas memperlihatkan kejadian KEK sudah lebih dari 20\% yang merupakan masalah kesehatan masyarakat. ${ }^{7}$ Untuk menanggulangi masalah tersebut pemerintah meluncurkan program BOK ke seluruh Puskesmas. Penyaluran dana BOK juga dimaksudkan untuk meningkatkan upaya kesehatan promotif dan preventif. ${ }^{9}$ Mulai tahun 2012 Kementerian Kesehatan RI menyediakan anggaran untuk kegiatan PMT Pemulihan bagi balita gizi kurang dan ibu hamil KEK melalui dana Bantuan Operasional Kesehatan (BOK). Dengan adanya dana BOK di setiap Puskesmas, kegiatan penyelenggaraan PMT pemulihan diharapkan dapat didukung oleh pimpinan Puskesmas dan jajarannya. PMT pemulihan bagi anak usia 6-59 bulan dan bagi ibu hamil KEK dimaksudkan sebagai tambahan, bukan sebagai penggganti makanan utama sehari-hari. PMT dimaksud berbasis bahan makanan lokal dengan menu khas daerah yang disesuaikan dengan kondisi setempat. ${ }^{9,} 10$

Berdasarkan Keputusan Menteri Kesehatan Republik Indonesia nomor 369 tahun 2007 tentang standar profesi bidan mengenai intervensi ibu hamil dengan KEK, dapat dilakukan dengan cara melakukan rujukan ke petugas tenaga gizi serta berkolaborasi untuk membantu memonitoring serta mengevaluasi asupan pemberian makanan dan kenaikan berat badan. Tetapi apabila tidak ada tenaga kesehatan gizi maka bidan dapat melakukan edukasi pola makan, pemberian makanan tambahan, serta melakukan monitoring dan evaluasi. 9,11

Hasil penelitian yang dilakukan di Kota Surabaya mengemukakan bahwa pemberian makanan tambahan (PMT) mampu memberikan perubahan status gizi ibu hamil KEK menjadi normal. Tetapi masih terdapat faktor lain yang mempengaruhi status gizi ibu hamil KEK seperti pola makan, konsumsi makanan, status ekonomi, status kesehatan dan faktor internal seperti beban kerja berlebihan dan pengetahuan gizi kurang baik. ${ }^{12}$ Pada saat ini masih banyaknya masalah kesehatan yang berkaitan dengan status gizi ibu hamil dengan kurang energi kronik. Berdasarkan hasil wawancara dengan kader bahwa pada bulan November sampai Desember 2015 di Desa Cipacing Kecamatan Jatinangor angka kejadian KEK berkisar 15 orang ibu hamil. Belum ada penelitian lebih lanjut untuk masalah gizi di desadesa lain wilayah jatinangor tersebut. Penelitin ini bertujuan untuk mengetahui survei intervensi ibu hamil kurang energi kronik (KEK) di Kecamatan Jatinangor tahun 2015. Berdasarkan permasalahan di atas, penulis ingin melakukan 
penelitian dengan judul "Survei Intervensi Ibu Hamil Kurang Energi Kronik (KEK) Di Kecamatan Jatinangor Tahun 2015".

\section{Metode}

Penelitian ini bersifat survei deskriptif dengan pendekatan cross sectional. Tujuan rancangan ini adalah menggambarkan secara komprehensif intervensi mengenai kejadian KEK pada ibu hamil secara berkala dalam kurun waktu tertentu. Populasi dan sampel yang diambil adalah seluruh ibu hamil dengan KEK di Kecamatan Jatinangor Kabupaten Sumedang. Data yang diperoleh dari Puskesmas Cisempur dan Puskesmas Jatinangor, ibu hamil dengan KEK sebanyak 112 orang. Teknik pengambilan sampel pada penelitian ini adalah total sampling yakni mengambil semua ibu hamil dengan KEK yang telah dilakukan intervensi. Pengambilan data dikumpulkan sejak 12 Agustus sampai dengan 18 Agustus 2015 di Wilayah Kecamatan Jatinangor. Setelah diberikan kriteria inklusi dan eksklusi, jumlah ibu hamil dengan KEK menjadi 33 orang.

Kriteria inklusi pada penelitian ini adalah ibu hamil dengan KEK yang diberikan intervensi. Sedangkan kriteria eksklusi pada penelitian ini adalah ibu hamil dengan KEK yang tidak bersedia menjadi responden, ibu hamil dengan KEK yang mempunyai penyulit obstetri, ibu hamil KEK yang tidak memiliki buku KIA, dan ibu hamil KEK yang tidak berada di desa Wilayah Kecamatan Jatinangor/ sedang berada di luar kota saat pengambilan data. Analisis data yang digunakan yaitu univariat dengan perangkat lunak (Ms. Excel). Kemudian di sajikan dalam bentuk tabel untuk menggambarkan intervensi dari ibu hamil kurang energi kronis (KEK).

Pada penelitian ini sudah mendapatkan ijin penelitian dari komite-etik FK UNPAD

\section{Hasil}

Data yang didapat sebelum diberikan kriteria inklusi dan ekslusi dari penelitian ini adalah 112 ibu hamil dengan kurang energi kronik (KEK).

Hasil setelah diberikan kriteria inklusi dan eksklusi sebanyak 33 orang ibu hamil dengan KEK. Dapat dilihat pada Tabel 1. Bahwa sebanyak 33 orang atau $29,5 \%$ ibu hamil dengan KEK di Kecamatan Jatinangor mendapatkan intervensi.

Setelah diketahui ibu hamil dengan KEK terintervensi sebanyak 33 orang. Kemudian, ibu hamil dengan KEK di lihat berdasarkan intervensi pemeriksaan berat badan (BB) dan pemeriksaan lingkar lengan atas (LiLA).
Pada Tabel 2. menunjukan intervensi dilakukannya pemeriksaan BB dan LiLA pada Ibu Hamil dengan KEK sebanyak 100\%. Artinya, sebanyak 33 orang ibu hamil dengan KEK, diberikan intervensi BB dan LiLA pada saat pertama kali ibu tersebut memeriksakan kehamilannya dan setelah dilakukan intervensi mengenai konseling kesadaran gizi (Kadarzi) atau pemberian makanan tambahan (PMT). Intervensi selanjutnya berdasarkan konseling kesadaran gizi (Kadarzi). Pada Tabel 3. dapat dilihat ibu hamil dengan KEK yang diberikan kadarzi sebanyak $100 \%$. Kemudian, pada Tabel 4. Ibu Hamil dengan KEK di intervensi berdasarkan pemberian makanan tambahan (PMT). Hasil yang didapatkan, ibu hamil dengan KEK yang mendapatkan PMT hanya 12 orang atau $36,3 \%$ saja.

Tabel 1 Jumlah Ibu Hamil KEK yang Mendapat Intervensi dan tidak Intervensi

\begin{tabular}{lcc}
\hline Kategori Ibu Hamil KEK & $\mathrm{n}$ & $\%$ \\
\hline Mendapatkan intervensi & 33 & 29,5 \\
Tidak intervensi & 79 & 70,5 \\
Total & 112 & 100 \\
\hline
\end{tabular}

Tabel 2 Intervensi BB dan LiLA pada Ibu Hamil dengan KEK

\begin{tabular}{|c|c|c|c|c|c|c|}
\hline \multirow{3}{*}{$\begin{array}{l}\text { Antopometri } \\
\text { Ibu Hamil } \\
\text { dengan KEK }\end{array}$} & \multicolumn{4}{|c|}{ Intervensi } & \multirow{2}{*}{\multicolumn{2}{|c|}{ Total }} \\
\hline & \multicolumn{2}{|c|}{$\begin{array}{c}\text { Sebelum } \\
\text { (K1) }\end{array}$} & \multicolumn{2}{|c|}{ Sesudah } & & \\
\hline & $\mathrm{n}$ & $\%$ & $\mathrm{n}$ & $\%$ & $\mathrm{n}$ & $\%$ \\
\hline $\begin{array}{l}\text { Berat Badan } \\
\text { (BB) }\end{array}$ & 33 & 100 & 33 & 100 & 33 & 100 \\
\hline $\begin{array}{l}\text { Lingkar } \\
\text { Lengan Atas } \\
\text { (LiLA) }\end{array}$ & 33 & 100 & 33 & 100 & 33 & 100 \\
\hline
\end{tabular}

Tabel 3 Intervensi Kadarzi pada Ibu Hamil dengan KEK

\begin{tabular}{lcc}
\hline Kadarzi Ibu Hamil KEK & $\mathrm{n}$ & $\%$ \\
\hline Diberikan & 33 & 100 \\
Tidak Diberikan & 0 & 0 \\
Total & 33 & 100 \\
\hline
\end{tabular}

Tabel 4 Intervensi Pemberian Makanan Tambahan pada Ibu Hamil dengan KEK

\begin{tabular}{lcc}
\hline $\begin{array}{l}\text { Pemberian Makanan Tambahan } \\
\text { (PMT) pada Ibu Hamil KEK }\end{array}$ & $\mathrm{n}$ & $\%$ \\
\hline Diberikan & 12 & 36,3 \\
Tidak Diberikan & 21 & 63,7 \\
Total & 33 & 100 \\
\hline
\end{tabular}




\section{Pembahasan}

Dari hasil penelitian yang dilakukan di wilayah kerja Puskesmas Jatinangor ditemukan kasus ibu hamil dengan kurang energi kronik (KEK) terintervensi sebanyak 33 orang atau 29,5\%. Angka tersebut diambil dari buku kohort dan penapisan gizi di Puskesmas Jatinangor dan Puskesmas Cisempur. Mengingat tingginya perpindahan penduduk di Jatinangor, ibu hamil tahun 2015 yang masih menetap di Wilayah Kecamatan Jatinangor dan memiliki buku KIA sekitar 33 orang.

Berdasarkan teori yang didapat ibu hamil dengan kurang energi kronik (KEK) di sebabkan beberapa faktor penyebab yaitu, asupan makanan yang kurang dan penyakit kronis. Sedangkan, faktor risiko yang bisa mempengaruhi yaitu, asupan makanan yang kurang, tingkat pendidikan, tinggi badan ibu, ibu tidak bekerja, posisi ibu dalam rumah tangga, lingkungan rumah di pedesaan, ibu hamil tidak dalam ikatan perkawinan, serta status Ekonomi. ${ }^{18}$

Adapun komplikasi yang dapat dialami, yaitu berat badan ibu tidak bertambah normal, keguguran, prematur, pertumbuhan janin terhambat, bayi lahir mati, kematian neonatal, cacat bawaan, anemia pada bayi, IUFD, BBLR, gizi kurang, serta gangguan pertumbuhan dan perkembangan. ${ }^{7,17}$

Untuk itu perlu intervensi yang dilakukan terhadap ibu hamil dengan KEK. Tabel 2. menunjukan bahwa seluruh ibu hamil KEK, sebelum dan setelah intervensi dilakukan pemeriksaan antropometri timbang berat badan dan pemeriksaan lingkar lengan atas. Tujuan melakukan pemantauan BB dan LiLA yaitu, untuk mengetahui tingkat keberhasilan dan kemajuan status gizi ibu hamil KEK dalam melaksanakan praktik intervensi. Kenaikan BB, penambahan LiLA, dan asupan makanan termasuk asupan makanan dari PMT ini merupakan indikator dari proses monitoring dan evaluasi. ${ }^{9}$

Pemantauan BB ini dilakukan setiap bulan sesuai dengan kelompok trimester ibu hamil dengan KEK. Sedangkan, LiLA diukur pada saat pertama kali ibu kunjungan di tenaga kesehatan (K1) dan setelah dilakukan intervensi selama 3 bulan. ${ }^{9,10}$

Hasil penelitian Kathleen dan Drora Fraser mengemukakan pemberian intervensi pada ibu hamil dengan KEK berefek positif pada bobot lahir bayi. ${ }^{23}$ Penelitian ini mengungkapkan bahwa risiko terjadinya IUGR atau BBLR dapat menurun jika dilakukan intervensi.

Penelitian lain yang dilakukan oleh Vika Kartika di Jawa Timur, mengemukakan deteksi dini dan intervensi dapat dilakukan menggunakan pengukuran lingkar lengan atas (LiLA). Pengukuran ini bertujuan untuk mengurangi risiko yang terjadi pada kehamilan dan kelahiran, sehingga perlu untuk melakukan pemeriksaan rutin pada masa antenatal (ANC). ${ }^{16}$

Kemudian Tabel 3. menunjukan bahwa seluruh ibu hamil dengan KEK menerima konseling kesadaran gizi (Kadarzi). Berdasarkan teori yang didapat konseling gizi dilakukan dengan tujuan membantu ibu hamil KEK dalam memperbaiki status gizinya melalui penyediaan makanan yang optimal, agar tercapai berat badan standar. Hal ini sesuai dengan standar pelayanan bahwa ibu perlu diberikan informasi, agar ibu dapat memperbaiki keadaannya. ${ }^{9}$

Penelitian Hapzah dkk juga mendukung teori yang didapatkan, bahwa konseling gizi dapat meningkatkan pengetahuan dan motivasi ibu hamil untuk menerapkan pola makan yang sehat selama hamil sehingga memiliki penambahan berat badan yang normal sebagai manifestasi dari pola makan yang sehat. ${ }^{24}$

Tabel 4. menunjukan bahwa, ibu hamil dengan KEK dilakukan intervensi pemberian makanan tambahan (PMT) sebanyak 36,3\%. Pemberian Makanan Tambahan (PMT) dibiayai dari dana Bantuan Operasional Kesehatan (BOK). Dari data yang didapat, PMT yang diberikan oleh Puskesmas Jatinangor dan Puskesmas Cisempur diperuntukan untuk keluarga tidak mampu/ Keluarga Miskin (Gakin). Sehingga, tidak semua ibu hamil dengan KEK mendapatkan PMT dari dana BOK tersebut. Menurut hasil penelitian Nugrahini, dkk. di Surabaya mengemukakan status ekonomi merupakan faktor tidak langsung yang berhubungan dengan kemampuan membeli dan memilih makanan yang bernilai gizi tinggi. ${ }^{12}$ Untuk itu, pemberian makanan tambahan diberikan kepada ibu hamil dari keluarga tidak mampu/ Keluarga Miskin (Gakin).

Berdasarkan teori yang didapat, tujuan pemberian makanan tambahan ini adalah untuk pemulihan gizi berbasis makanan lokal bagi ibu hamil dengan KEK. PMT dilakukan selama 90 hari dan evaluasi setiap bulan dengan melihat pertambahan berat badan dan LiLA, sehingga status gizi ibu menjadi normal. ${ }^{9}, 10$ Hal ini didukung dari hasil penelitian yang dilakukan di Kota Surabaya, mengemukakan bahwa pemberan makanan tambahan mampu memberikan perubahan status gizi ibu hamil KEK menjadi normal. ${ }^{12}$

Meskipun hanya 36,3\% ibu hamil yang mendapatkan pemberian makanan tambahan (PMT). Ibu yang telah diberikan konseling kesadaran gizi serta melakukan pemeriksaan rutin antenatal dapat meningkatkan perbaikan status gizi. Hal ini didukung oleh penelitian Haoyue 
Gao dkk, bahwa kepatuhan setidaknya untuk beberapa nutrisi yang direkomendasikan, dengan penekanan khusus pada pendidikan mengenai gizi dapat mengurangi kesenjangan status gizi yang terjadi. ${ }^{25}$

Apabila dalam pelaksanaan intervensi bidan mengalami kendala, maka dapat melakukan kolaborasi dengan tenaga kesehatan gizi dan Lembaga Pemberdayaan Masyarakat (LPM). Kolaborasi ini dapat dilakukan dalam hal pembuatan makanan tambahan lokal maupun dalam memotivasi ibu hamil. ${ }^{9}{ }^{21}$ Penelitian ini memiliki keterbatasan dalam pengambilan data, dikarenakan keterbatasan waktu dan akurasi pengambilan data. Hasil akurasi ini dipengaruhi oleh banyaknya ibu hamil dengan KEK yang tidak berada atau tidak bertempat tinggal di Kecamatan Jatinangor.

Dari hasil penelitian yang berjudul "Survei Intervensi Ibu Hamil dengan Kurang Energi Kronik (KEK) Tahun 2015 di Wilayah Kecamatan Jatinangor", maka diambil kesimpulan sebagai berikut, ibu hamil dengan KEK yang mendapatkan intervensi di Kecamatan Jatinangor sebesar $29,5 \%$. Dari ibu hamil yang dilakukan intervensi, $100 \%$ dilakukan penimbangan berat badan, pemeriksaan LiLA dan konseling kesadaran gizi (Kadarzi), serta untuk pemberian makanan tambahan (PMT) sebesar 36,3\%.

Bedasarkan simpulan yang telah diambil, maka saran yang dapat diberikan yaitu, puskesmas dapat memfasilitasi bidan untuk mengikuti pelatihan Midwifery Update (MU) dalam mendeteksi dini faktor risiko, komplikasi dan dampak yang terjadi pada ibu hamil dengan KEK. Kemudian, bidan dapat meningkatkan kualitas intervensi dan kolaborasi dengan tenaga gizi, dalam memberikan asuhan terhadap ibu hamil dengan KEK mengenai konseling kadarzi dan pemberian makanan tambahan. Serta berkolaborasi mengenai pembuatan makanan lokal dengan tenaga gizi. Hal ini dapat dilakukan pada saat pelaksanaan kelas ibu hamil.

\section{Daftar Pustaka}

1. Salam RA DJ, Ali A, Lassi ZS, Bhutta ZA. . Maternal undernutrition and intrauterine growth restriction. Expert Riview Obstet Gynecol;2013.

2. Devgun P, Mahajan SL, Gill KP. Prevalence of chronic energy deficiency and socio demographic profile of women in slums of Amritsar city, Punjab, India. Science International Journal of Reasearch in Health. 2014;2(2).

3. Abraham S, Miruts G, Shumye A. Magnitude of chronic energy deficiency and its associated factors among women reproductive age in the Kunama population, Tigray, Ethiopia, in 2014: BioMed Central Nutririon; 2015.

4. Sugiarsih U, Wariyah. The relationship between socio-economic status with haemoglobin level. Kebidanan Karawang Poltekkes Bandung; 2013.

5. Subasinghe AK, Walker KZ, Evans RG, Srikanth V, Arabshahi S, Kartik K, et al. Association between Farming and Chronic Energy Deficiency in Rural South India. Public Library of Science- PLoS ONE; 2014.

6. Wisnu. Hasil Riskesdas 2013 Terkait Kesehatan Ibu. Departemen Kesehatan; 2013 [cited 201521 November]; Available from: http://www.kesehatanibu.depkes.go.id/ archives/678.

7. Sumarno I. Faktor risiko kurang energi kronis pada ibu hamil di Jawa Barat Panel Gizi Makanan; 2005.

8. Kesehatan PDdI. Ringkasan Eksekutif Data dan Informasi Kesehatan Provinsi Jawa Barat. In: Indonesia KKR, editor. Jawa Barat: Kementrian Kesehatan Republik Indonesia; 2013.

9. Wirjatmadi B, Nurdiati DS, Irawati A, Pusponegoro A, Indriastuti YA, Siagian C, et al. Pedoman Penanggulangan Kurang Energi Kronik (KEK) Pada Ibu Hamil: UNICEF, WHO, IBI; 2014.

10. Ditjen Bina Gizi dan Kesehatan Ibu Dan Anak Kementrian Kesehatan RI. Panduan penyelenggaraan pemberian makanan tambahan pemulihan bagi balita gizi kurang dan ibu hamil KEK (Bantuan Operasional Kesehatan). Jakarta: Kementerian Kesehatan RI; 2012.

11.Menteri Kesehatan RI. Keputusan mentri kesehatan RI nomor 369/MENKES/SK/ III/2007. Jakarta: Mentri Kesehatan RI; 2007.

12. Nugrahini EY, Effendi J, Herawati D. Asupan energi dan protein setelah program pemberian makanan tambahan pemulihan ibu hamil kurang energi kronik di puskesmas kota surabaya. Universitas Padjadjaran; 2013.

13. Kesehatan BPdP. Hasil Riset Kesehatan Dasar 2013. In: RI MK, editor. Jakarta: Mentri Kesehatan RI; 2013.

14. Yuwono SR, Minarto, Irianto SE, Syaiful I, Harmany A, Sitolonga YM, et al. Asuhan gizi di puskesmas: pedoman pelayanan gizi bagi petugas kesehatan. Jakarta: Kementrian Kesehatan RI dan WHO Indonesia; 2012.

15. Moegni EM, Ocviyanti D. Buku saku pelayanan kesehatan ibu di fasilitas kesehatan dasar dan rujukan. Jakarta: WHO, POGI, IBI; 2013. 
16. Mahirawati VK. Faktor- faktor yang berhubungan dengan kekurangan energi kronik (KEK) pada ibu hamil di kecamatan kamoning dan tambelangan, kabupaten sampang, jawa timur. Pusat Humaniora Kebijakan Kesehatan dan Pemberdayaan Masyarakat, Badan Litbang Kesehatan, Kemenkes RI; 2014.

17. Indrasanto D. Glosarium data dan infomasi kesehatan. Pusat Data dan Informasi Departemen Kesehatan Republik Indonesia; 2006.

18. Sandjaja. Risiko kurang energi kronis (kek) pada ibu hamil di indonesia. Pusat Penelitian dan Pengembangan Gizi dan Makanan, Depkes RI; 2009.

19. Syafiq A, Setiarini A, Utari DM, Achadi EL, Fatmah, Kusharisupeni, et al. Gizi dan kesehatan masyarakat. Jakarta: Rajawali Pers; 2014.

20. Henderson, Christine. Konsep Kebidanan. Jakarta: EGC; 2006.
21. Ralph B. Buku saku obstetric dan ginekologi. Jakarta: EGC; 2009.

22. Daba G, Beyene F, Fekadu H, Garoma W. Assessment of Knowledge of Pregnant Mothers on Maternal Nutrition and Associated Factors in Guto Gida Woreda, East Wollega Zone, Ethiopia. Nutrition and Food Science; 2013.

23. Abu- Saad, Kathleen, Drora Fraser. Maternal nutrition and birth outcome. Israel: Oxford Journal; 2010.

24. Hapzah, Veni Hadju, Saifuddin Siradjuddin. Pengaruh konseling gizi mikro dua kali seminggu terhadap peningkatan kadar hemoglobin dan asupan makanan ibu hamil. Media Gizi Masyarakat Indonesia Makassar; 2013.

25. Gao H, Stiller CK, Scherbaum V, Biesalski HK, Wang Q, Hormann E, et al. Dietary intake and food habits of pregnant women residing in urban and rural areas of deyang city, sichuan province, china. nutrients; 2013. 